\title{
Taxpayer to Taxpayer Relation
}

\begin{abstract}
To exchange and thus to create reciprocal relations is a human propensity and even a necessity for human solidarity. To exchange is an important aspect of what produces and maintains social relationships, and as such is one of the cornerstones in the making of society. But when Sweden has a law that says that all exchanges having value, regardless of how they are compensated, ought to be subject to tax assessment it becomes tricky. Do Swedes not exchange in private at all? Or are they all cheating when it comes to taxes? The Agency aims to increase compliance by stating that everybody should provide their fair share; then reciprocity, as a result of economic exchanges between citizens without involving the state, becomes problematic.
\end{abstract}

Keywords Barter - Private-public division - Informalization - Share economy $\bullet$ Copy-cat reciprocity $\bullet$ Legitimate taxation

To exchange and thus to create reciprocal relations is a human propensity and, as Mary Douglas emphasizes in the Foreword to The Gift, is a necessity for human solidarity (Mauss 2002 [1990]: xiii). To exchange is an important aspect of what produces and maintains social relationships, and as such is one of the cornerstones in the making of society (Davis 1992). But when Sweden has a law that says that all exchanges having value, regardless of how they are compensated, ought to be subject to tax

(C) The Author(s) 2018

L. Björklund Larsen, A Fair Share of Tax, https://doi.org/10.1007/978-3-319-69772-7_3 
assessment it becomes tricky. Do Swedes not exchange in private at all? Or are they all cheating when it comes to taxes?

These taxpayer to taxpayer relations are the subject of this chapter. We will continue to untangle the contemporary motto that steers the Agency's strategies in order to explore the insights it has about informal exchanges, for example those between taxpayers, where the state and its public institutions do not take part. When a risk analysis assessment project performed at the Agency showed that reality differed from previous messages reported about Swedish tax compliance, the resulting report was not disclosed (Björklund Larsen 2017). Its strategies were at risk. As one manager at the Agency commented on a presentation of the report: 'We have a problem when we say that most taxpayers provide their fair share when in reality they do not.'

As we will see, there are a number of intriguing implications in this very moral message coming from a 'mere' government bureaucracy, albeit an important cornerstone for the Swedish welfare state. That the Agency publishes such a motto means that it takes a position not only as a governmental bureaucracy, but also as a societal actor that engages in citizens' interrelations in order to achieve tax compliance. It has to do so given the tax law that governs personal income, but also because it recognizes that people who trust each other pay more willingly into a common treasury.

I find it important to make a distinction between society and state here. Simply put, a society is a group of people involved in social interaction (Latour 1984). These people can share the same geographical or social territory and adhere to similar cultural values. Societies are characterized by numerous relationships between individuals; a given society may be described by the specific arrangements of such relationships. A state on the other hand is peopled by subjects who live under a specific system of government. Such subjects are ruled by specific political institutions. People more or less voluntarily belong to societies (in the plural). Often society is the state, for example Swedish society, but societies are also clubs and other organizational structures of people who share the same interests, beliefs or values. People are usually subjects of one state, sometimes depending on laws and regulations governing citizenship, but often feeling adherence to many societies.

We will see how reciprocity as a result of economic exchanges between citizens becomes problematic for the Agency. In its aim to increase compliance by stating that everybody should provide their fair share, it is in its 
relation to the taxpayers; it is fulfilling its fiscal aim. Taking reciprocity between people seriously is a different matter. When people exchange without taking the state into consideration, do such exchanges become tax avoidance strategies if interpreting the law to the letter-which, as we will see, the Agency does if provoked.

Yet Swedes do exchange-a lot. This chapter is thus about the everyday exchanges between people; about the reciprocity invoked in exchanges that if the law is read to the letter ought to be subject to tax. We will see how people find the rigid interpretation of the law incredulous, and how the different relations they invoke make for justified engagement in svart arbete. As Ruben, who works in the judiciary, says: 'You know, I do not identify with the state. But I would not cheat on Svensson living next door, would I? But somehow he belongs to the state as well.'

\section{The Agency's View}

People who perceive that their compatriots contribute pay taxes more willingly themselves. This insight is recognized and discussed across a wide range of disciplines. For example, economic psychologists have explored various components of equity theory and run experiments on the fair distribution of resources between taxpayers (cf. Folger 1986); economists delve into tax compliance as a gamble that is independent of loyalty, but instead is based on the willingness to pay that depends on risk taking (Cowell 1990; Falkinger 1995: 42); and legal scholars study the distribution of fairness in terms of the interpretation of laws (Gribnau 2015; Westerman 2014). Citizens assess their payments of taxes and fees not only in relation to what they as individuals receive from the state (as we saw in Chap. 2), but they also compare their contribution with their perceptions of what their fellow citizens pay-how they identify themselves as members of that group (cf. Taylor 2002).

The impact of this research is made visible in the Agency's motto, ${ }^{1}$ prominently placed on its website and pointed out in its strategies and communication with Swedish society: 'Our vision is a society where everybody wants to do one's fair share.' We drilled down into this message in Chap. 2, to see that for the Agency Swedish society is synonymous with the state. Regardless of what a citizen thinks about taxes, what legal entity s/he occupies and what knowledge s/he holds, the Agency's message is that all individuals pay in order to contribute to the state. Or at least ought to pay; and this is what the Agency strives for-it is a vision after all. 
The Agency's book Right from the Start (Skatteverket 2005) elaborates on this vision. The book had several aims: to provide input for internal discussions; to relate research and knowledge about the tax gap; to propose strategies to diminish the gap. It related contemporary research and knowledge about tax compliance, mainly from research into psychology and criminology.

According to the book, the Agency would increasingly focus not on the evaders, but on those who complied. The Agency identified research on what makes people follow rules and regulations - not only in tax research, but over a broader spectrum of how norms and behaviour are shaped. The book decisively took a step away from explaining tax compliance from a purely economic standpoint, stating that ' $[\mathrm{r}]$ esearch clearly shows that financial incentive, as well as the risk of detection and punishment, is less important than the influence of norms and moral values' (Skatteverket 2005: 6), adding that there was 'nothing to indicate that the tax burden has any influence on the degree or extent of tax evasion' (ibid.: 7). It is the level of acceptance among taxpayers that matters. The Agency therefore saw one of the more important tasks of a tax administration to be influencing such norms (ibid.: 127). Instead of controlling and auditing after tax returns had been handed in and taxes paid, the Agency increasingly aimed to became proactive and to find measures that would make taxation more relevant 'right from the start'.

Reciprocity was one of the strongest norms identified in this work. The definition proposed was 'that people "repay" a certain kind of behaviour' (Skatteverket 2005: 6) and that '[a]n individual will choose to cooperate and to contribute to the common good if others are doing the same' (ibid.). But as we know by now, tax compliance is not only based on doing what others do; there is also the element of conditional cooperation. This means that attention is paid to the notion that 'the extent to which others also contribute triggers more or less cooperation and systematically influences the willingness to contribute' (Frey and Torgler 2007: 137). The Agency regards such norms developed through evolution and are both socially learnt and biologically inherited (Skatteverket 2005: 6), adding that it is not only taxation that is concerned with such norms.

Based on the belief that reciprocity can be seen as part of the history of mankind, it was important for the Agency not to be seen as an imposer of rigid control, detection and punishment if people were found to be avoiding taxation. The idea was to encourage compliance and thereby also create good role models. People comply because they regard the rules to 
be just and they try to follow them, not because they are afraid of being punished. Try is key here, as the Agency recognizes that tax laws, and its interpretations of those laws, are not always easy to apply in practice (Stridh and Wittberg 2015). Every taxpayer should to the largest extent be given help in order to comply. The result would be that they would trust that all other taxpayers were complying to the same extent. The Agency's compliance work was centred on collecting 'the right tax' from each taxpayer.

Simultaneously with the compilation of Right from the Start, a large analysis project on black work, swart arbete, took place at the Agency. According to the project leader, they were 'trying to do the puzzle' about svart arbete (cf. Björklund Larsen 2010: 10). Among many other findings, an estimate of 13 per cent of the workforce had participated in work that had been settled informally. This included 'reciprocal' services, which are those exchanged without monetary compensation. The estimates were based on an interview survey with people who said that they had performed work svart; two-thirds came from work performed for households and one-third was income from work done for other companies-informally. The Agency recognized the difficulty of pinning down such jobs with current review methods, and also stated that there was very little overlap with income found in audit controls (Skatteverket 2006: 61). ${ }^{2}$ There was no exact definition of 'reciprocal services' given in the above estimate, but it clearly included barter (ibid.: 57).

Insights from these projects governed strategies for the next decadeon the one hand ensuring that all citizens were providing their fair share and fulfilling their obligations as taxpayers but on the other hand acknowledging insights from the project on spart arbete where proposals were made to simplify the tax system. The system was argued to be complicated, outdated and not in accordance with the general opinion of citizens (Skatteverket 2007).

This was in the mid 2000's and the strategy of creating role models, and thereby compliance, has been downplayed during the last years as the emphasis has increasingly been on making audit controls more visible. It is thought that audits should be more integrated into work with other system measures and communication strategies (Stridh and Wittberg 2015). There are taxpayers who do not comply, and when the Agency shows that they will be found and made to pay, societal tax compliance will ceteris paribus increase. Audit controls have historically been very expensive and cumbersome to carry out, but digitalization efforts at the Agency (as everywhere 
else in society) make them increasingly simple, at least on a screening level, as diverse digital methods such as scorecards and data-mining are applied to taxpayer information and annual returns. It is important to emphasize here that the Agency does not sample risky taxpayers based on defined categories such as gender, age, education or place of birth, but on combinations of what is said to be risky behaviour. ${ }^{3}$ Looking for non-compliant taxpayers, the Agency is not interested in people's attributes but in their practices.

This way of looking at risky behaviour directs our scrutiny towards how exchanges are made-and especially on the relations that such exchanges are said to create.

Although the Agency recognized that creating and maintaining reciprocal relations between people plays a role in tax compliance, exchanges that are seen to create reciprocity are not something they pursue in practice. The values of barter ought to be assessed for tax, but the Agency recognizes the futility in pursuing such behaviour (Skatteverket 2006). As one manager at the Agency said: 'It is not the type of exchange we are interested in pursuing.'

Recall the law-all exchanges that have value, regardless of how they are remunerated, ought to be subject to tax assessment. Although hardly anyone declares the mundane exchanges that have value in their yearly tax return form, a former expert at the Agency wanted to test the rules. ${ }^{4}$ His account underscores the fact that the Agency has to be strict when challenged and that the letter of the law must be observed.

The expert, let us call him Sven, declared an extra income of 250 krona on top of his income as an Agency employee in the obligatory annual income tax return. This was the estimated value of a dinner that his daughter had given him in return for babysitting his grandchild one evening when his daughter went to the cinema. He was subsequently taxed on this amount, a result he appealed against stating two objections. First was that the social relationship between the exchangers was very close; he received compensation from his daughter. In addition, the sum received was less than 1000 krona, an amount that was less than the lower limit of what needed to be declared at the time. This appeal was turned down on both counts in a three-page letter. The argument was twofold. First, the sum received could not be regarded as any other type of taxable income and was instead added to his professional salary (however, no social contributions needed to be paid as the amount was less than 1000 krona). Second, the fact that the relationship between the exchangers was between child and parent did not change the decision. 
Obviously there are millions of exchanges like this taking place daily, and the majority of people do not pay the slightest attention to the fact that they ought to be subject to tax. These everyday exchanges where people help each other are a general, common, human fact, and such bartering creates, maintains and strengthens relations-including among Swedes.

The pertinent question for the Agency, and for tax compliance, is where you draw the line between taxable and non-taxable. How does a service become explicit tax cheating in the eyes of the Agency? Is it the extent of organization? The amount exchanged? The relationship between exchangers? Or when the relationship is assessed-before or after the exchange has taken place? Exchanges create relations, so it follows that these aspects are vital in order to understand issues that impact tax compliance.

Imagine a bloke next door who bikes a lot. He is also good at maintaining bikes; he takes care of his own, as well as his parents' and siblings' bikes. He knows the art of fixing flat tyres; he oils bikes to prevent squeaks, shrieks, and squeals; he wraps the handlebars; puts the chain back in place; changes worn brake pads-you name it. He does this for his family, friends, friends of friends, perhaps the entire neighbourhood. Perhaps you can knock on his door and ask him to do it, or it might be common knowledge that on Sunday afternoons as well as on Tuesday evenings he is usually there to help you out?

So when he has fixed a flat tyre, how do you compensate him? The bike fixer has clearly helped you with a service. Does he do this for nothing? Do you hand him a few 100 krona notes (the amount depending on how much time he took)?

These are tricky questions for the Agency, and it knows about these unclear borderline issues-especially when the work is performed in private. What is taxable, they ask rhetorically (Skatteverket 2008: 62). A child who helps out at home and gets compensation? Or a teenager who cuts the lawn-does it matter if this is done at home or at a neighbour's house? What about the plumber who helps his neighbour, an auditor, to paint his house and in return gets help with an application for a building permit? Or if the same plumber fixes the auditor's leaking pipe in return for help with his book-keeping (ibid.)?

The Agency thus clearly understands the challenge of drawing the line between taxable and non-taxable issues, bringing out age, relationship, type of work and professionalism in the exchanges performed-not to mention the type of compensation. The Agency is seldom very explicit 
about such a border, a fact that probably increases its legitimacy (Björklund Larsen 2017: 154).

Yet it reflects the Agency's knowledge about the types of exchanges most Swedes engage in. Most of the Limningers seem to know that exchanges with value ought to be subject to tax. Yet in some instances it is seen to be acceptable to avoid reporting such exchanges. In what follows, we will examine such instances and how people justify them. In all cases, reciprocity is invoked as justification.

\section{BARTER}

To facilitate and economize when exchanging things and services with each other, Limningers, and probably most other Swedes, barter.

Barter is a direct exchange of services or commodities without using a medium of exchange such as money, yet it involves an element of calculation. It has often been depicted as old-fashioned and primitive, a less sophisticated form of payment than cash. However, research into contemporary exchanges has brought the concept back into the limelight. It shows that bartering is done for a variety of reasons. People in general barter when they prefer not to use money (Humphrey and Hugh-Jones 1992), or to evade taxes and fees in general (Hart 2001). Citizens in the Soviet Union performed blat as a way of getting around the red tape (Ledeneva 1998); while popolino in a working-class section of Naples barter in order to avoid contact with the authorities (Pardo 1996). Barter can be organized with intermediate payments such as local currencies like Ithaca HOURS (Maurer 2005) and Local Exchange and Trading Systems (LETS) (Williams 2012) not to mention the exponentially growing sharing economy, where at least some of the exchanges taking place can be said to be barter (Schor 2016). Barters have often been depicted as nonreciprocal (Sahlins 1972) and performed on the same moral level as theft (Gregory 1994), involving minimal trust between exchangers with little impact on social relations (Zelizer 2005). Yet barter usually occurs between people who already know each other, among family and friends, neighbours, colleagues, professional networks, or are made to feel they do so, facilitated by ratings in the digital sharing economy.

So people opt to barter and help each other for manifold reasons. It can be a habit, a way of being friendly, to build and maintain relations both political and ideological; but also because it is cheaper than buying (the calculation element being more pronounced). The exchangers already 
have a certain amount of trust as they help each other; barter is a practice that can take place outside the formal market and the auspices of the state. Money is therefore not needed as remuneration; a service is performed in exchange and the substantial amount of tax due can be avoided. In the Swedish context, it becomes svart arbete-one of those widespread practices that challenge laws, rules and norms. Acknowledged as wrong, it is in many instances acceptable. These exchanges highlight the inadequacies of the formal economy, which are pragmatically resolved by the actors who are subject to it (Björklund Larsen 2013a).

In order to understand bartering the entire value system in which the barter takes place has to be appraised (Humphrey and Hugh-Jones 1992: 15). An important attribute of the Swedish institution of barter is that taxation makes the exchange of services much, much more expensive. Barter is a means of economizing.

Björn, a trucker, exemplifies the impact of the difference between the costs for formal and informal work in a straightforward way:

I think you should have it one to one. With what you earn for an hour of work, you should be able to pay someone else to do things you do not have time to do. But it is not like that today. You earn 100 krona and what's left is 50 . With that you have to pay 200 for someone to come and do something for an hour. That's not fun. If you were to pay him formally, you would have to pay yet another 100. It does not feel OK.

Settling a deal by bartering can of course be more complicated than paying cash, as the worth of service and/or product has to be estimated by other means than in an equivalent monetary comparison. The objects exchanged are often different, and it seems of no great concern if one of the providers gets a bit 'more' than the other. The difference is that the calculation relates to what the services would have cost on the official market with invoices, taxes and fees included. A painter can exchange work (for private use) with an electrician. Even if time spent is not equal, both can be content with the outcome of the deal, as having to buy the services would have cost three to four times what their respective work effort was worth net. For those with skills to offer, bartering is much more economical than purchase.

Talking about barter in terms of closer relations lets Swedes justify those purchases that they know ought to be subject to tax. Barter is clearly made more licit than buying a service svart, regardless of whether the reason for 
the purchase is pure survival, not having enough money or attempting to get a service performed as cheaply as possible. There are also those who have no knowledge to offer as a barter, thus making cash payment the only alternative (usually higher educated people without practical skills). However, such a justification is trickier, since if money alone is used for compensation, a quite clear division between the licit and the illicit exchange is drawn. In the following we will see diverse examples of Limningers who justify their svart purchases by talking about them as barter. Closeness of relations, the extent of organization, scope of exchange and value calculated make exchanges more or less licit, but even when the deals are settled with money ideas of barter can be invoked (cf. Björklund Larsen 2013a).

\section{TAXPayer Views ON BARTer}

Discussing the proximity of relations and if 'helping out' ought to be subject for tax assessment, Pelle, an engineer, tells me about his uncle who gathered close family and other relatives during a weekend for a 'painting party' at his newly built house. Pelle asks rhetorically: 'Should that be seen as illegal? There are probably a few who would insist that it is svart arbete. I would never agree with that.' All the relatives helped to paint, and when it was finished they were invited to a good meal. In this case Pelle's uncle used family relations to get work done while simultaneously saving money. The outcome was probably that social relations in the family were strengthened while a fun event was created from tedious painting. One could see this as pure bartering - they got a meal after all-but more explicitly it is an expression of maintaining closer relationships. In this family we help each other and we have fun together; too bad if such services are also worth some money and could thus be seen as taxable.

A monetarily settled service makes for increasingly illicit types of svart arbete. Sometimes even those can be considered licit, which I shall return to later. Pelle voices what many said when he distinguishes between svart arbete and bartering services. He says: 'If a friend of mine is excellent at doing one thing and I, on the other hand, at doing something else, we exchange time with each other. For example, I am good at tiling and he helps me nail. That's definitely not svart arbete, whereas it is when you exchange your working time for money.'

Knowing the relation to the provider of the work is vital if it is to be seen as taxable or not. The Limningers almost spoke in chorus. 'If we are friends or family, then it is definitely not svart,' says Carl Johan. Hasse: 'It 
should not be taxed if it's mates doing the work. If I fix his garden and he my car. Which really [according to the law] is svart.' Janne points out that these are things that keep people together; not everything that he needs should be bought on the market. Most Limningers recognized the inherent problem of drawing the line between what is a help between friends, family and people in general, and what on the other hand can be considered spart.

Jenny, a hospital cleaner, muses on the border: 'There is a fine line between svart arbete and bartering services for something in return. Which I really think is a good idea. You know, if I am good at something and you at something else, can't we barter services? And not an öre is exchanged.' She gets really excited at the thought, but also raises a warning: 'You cannot do this as you like, not for big amounts of money. The value cannot be too high.' What becomes with this reasoning, is that helping each other becomes almost a bad thing, at least in relation to the state.

\section{Business and Private Life}

Self-employed people know that they ought to draw a distinct line between business and private costs; in reality it can be quite difficult but may also provide manifold instances of getting things cheaper-much cheaper. This means that certain transactions are made more reciprocal than they really are. 'There is no one who only barters, it would be criminal then,' says Sten, who runs a small furniture store. 'It is done in small proportions, bartering products with each other. For example, there is this shoe merchant I know; I get a pair of shoes from him and he gets a chair in return.'

Sten points to this relationship in bartering with his fellow shopkeepers. He needs a pair of shoes. The value of these is (mentally) jotted down by his acquaintance who sells shoes. At a later date, he finds a chair to his liking, the price of which Sten in his turn notes somewhere. If the values of shoes and chair are fairly equivalent the deal is closed, even if the relationship with the counterpart is not (cf. Graeber 2001: 220). Any outstanding debt that has not been settled for some time they resolve with a more practical cash payment. An exchange that is beneficial for both thus maintains acquaintances and friendships, but is still concealed from the rest of society.

Tomas lives outside Limninge in a refurbished summer home with a neat, tidy garden. In one corner of the garden is an outdoor wooden spa tub, in another a pretty shed for garden tools. How this shed was built is 
an illustrative example of how one can barter through one's professional network. Tomas is a self-employed craftsman who works at many building and construction sites. He meets many people, has an extensive network to draw on and sometimes uses his professional relations to acquire materials for private use. When we talk about his involvement in svart arbete, he hesitates a bit and then says:

There is a shed up there. Now I am being really honest, it hasn't cost me many krona. I have exchanged services for materials. I've been at one building enterprise here and another there. 'So I ask, there is a stack of bricks behind there, are you going to use them?' 'No, they are left over from the construction of those forty apartments.' 'It is just about what I need for the garden shed I am about to build. If I just charge half for that control report I did, can I take those bricks?' 'Yes, you just take them. They will be got rid of anyway.' There are those types of examples.

Tomas used his professional knowledge to acquire materials for private use, basically for nothing, through customer relations. Not only are the objects dissimilar, but he also barters a service for a commodity. The relation between Tomas and the site manager is based on professional dealings, yet it is probably strengthened by having made a smart deal with a reduced invoice exchanged for a stack of bricks. This hidden barter is concealed in order to avoid taxation. It is an unequal exchange converted into a strict monetary value, as those bricks have a different use-value for the construction company than they have for Tomas. For the construction company they imply a cost, as they have to be taken away as rubbish, whereas for Tomas those bricks have the same market value as if he had bought them from a store. In addition, he did not have to spend time going to a store, buying them and bringing them home.

That such situations occur is known by the Agency. In the risk assessment project performed by them, a similar result for small business entities was discussed, although here the issue was faulty cost deductions. The analysts probed into the question holistically: why do such costs occur; how common are they; how much do they amount to (as part of a tax gap measure)? ${ }^{5}$ We saw Tomas barter products for reduced invoices in a transaction that was really a 'purchase' intended for private use but was mentally accounted for as part of his business activities. The barter was obviously cheaper, much cheaper (bought for non-taxed money without VAT), but it was also for many other reasons a good deal for both exchangers. 
Exchanges that take place in private as opposed to on the public arena (when at least one of the parties is acting in the role of a business entity or in another formal role) are usually said to make for a different relationship. Yet when the Agency thinks about such cost deductions among professionals, they draw on results from audit controls that show these entanglements are more common than the Agency imagined in its strategies stating that most pay their fair share.

The analysts discussed this repeatedly. Lacke provided numerous examples. 'When the neighbour borrows a business-owned trailer, it becomes a type of societal grease. Taxwise it is usage of a business asset (and thus subject for tax assessment).' Susanna added: 'There are so many situations when people buy assets for the business, yet assets that are used to help the family or friends. Then we start going beyond family members.' Where is the line drawn between legal and illegal? When each purchase could be thought of as either business or as private, it can be tempting to justify them all as business-related costs.

\section{An Example: Horse Trotting}

One issue of concern at the Agency that was repeatedly discussed was horse management. It is expensive and there are large economic incentives to incorporate such a hobby into other business activities, which would allow expenses to be deducted. Historically, horses have been used for a number of tasks in Sweden but are contemporarily viewed as a hobby for the elite, thus being deemed exclusive. ${ }^{6}$ From this point of view, owning horses sits badly with the idea of an equal Swedish society, yet not all 300,000 horses in Sweden are used for upper-class activities.

Greger, a factory worker, lives in a forested area in the south-east of Sweden where he has built a house next door to his grandparents' farm. He uses the attached stables to breed and train trotting horses, his big interest. There is nothing exclusive about Greger's homestead, yet he loves working with the horses, so his part-time factory employment is a way to survive. He has bred and trained at least ten horses, yet he cannot survive on what they bring in.

Greger barters-a lot-and not only in relation to his horse activities. In the trotting community, there is a lot of bartering going on, he says, as so many who are active there have very limited means. At home he exemplifies barter with the job he does with his excavator. He digs for his neighbour, but does not declare what he gets for it as an income. When I ask if 
it is money he gets, he replies: 'Sometimes. Most often he does something for me instead.' And he adds: 'It is not legal, you know.' So he barters, as do many other horse breeders, in order to be able to continue with his big hobby. Greger is yet another example of how people talk about exchanging services as barter; it is not always barter but it is talked about as such.

Back to the Agency and the risk assessment project. One issue that analysts thought would be subject to much cost deductions were the so-called hobby firms. To distinguish hobby activities from self-employment is a major concern of the Agency, which suspects that many citizens wish to register their hobby as a business activity, ${ }^{7}$ in order to facilitate the deduction of costs. In the risk assessment project, many considerations were made to distinguish between activities that can be referred to as hobbies and those that are viewed as commerce or industrial activities. The reason for this is that many hobby activities are expensive; if you can make them look commercial they can be transformed into a loss-making activity and therefore deductible (Björklund Larsen 2015). This idea came to nought; the random audit control could not identify any hobby firms. They probably exist, but among the firms sampled for the audit they passed under the radar.

\section{Business and Private Life Continued}

For the self-employed it is in practice difficult to separate business and private transactions, and this is also recognized by the Agency. There are so many instances where these spheres overlap in everyday practices that exchanges made in private-supposedly increasing reciprocity-are accounted for as a business activity in the market sphere, thereby creating less reciprocity.

Larry, a coastguard who is very able with his hands, reflects on this. When he started out working, there was always someone among his colleagues who had to do some work on his house, and all of the colleagues helped out. 'There were electricians, painters, carpenters- the lot. And everyone knew that next year it was someone else's turn and a few weeks would be spent there. This just organized itself without anyone commanding.' In Larry's story, there is a nostalgic, old-time camaraderiemen who gather in the summer, laughing and cracking jokes while making a veranda, an extension to the summerhouse or installing a new kitchen.

Yet when a group of professionals refurbishes a house for a client such bartering is not possible among the workmen. It becomes svartwork. Even if the intention is not to make it cheaper for the owner of the house- the 
client - this work is carried out by the workmen in their professional role. Such work is too organized and all transactions should be formal. There are various informal ways of exchanging work and things between the professionals that in the end have consequences on the tax system-usually the result being less tax collected. Monetary gains are not everything; a reason for not invoicing among the network of craftsmen can also be to avoid the extra administration it creates. It is boring and cumbersome, so it is easier to remember small favours and recompense them at some later stage.

The Agency says it understands the challenges in administrating VAT and invoices appropriately. As for cost deductions, there is always the challenge of determining if such costs have been used professionally or in private. This is meticulous, even nit-picky work and makes for the negotiation of many subjective evaluations. Instead of evaluating and arguing over such issues both internally and with the taxpayer in question, would it not be easier to apply a flat tax deduction, as most other countries do? The opportunity to invoke reciprocity in such cost deductions would be erased. The project manager, Lars, proposed that this issue should be looked into as part of the analysis work, to see if countries with flat tax deductions avoided the continuous evaluation problem that was encountered at small business audits.

It was of no use. A flat rate deduction would be much easier to explain and to administer, yet it was considered a non-question at the Agency. Gunnar, the manager at the analysis department explains why:

It is not seen as fair. The Swedish basic taxation principle is 'after each one's ability'. Any legal proposals have always carried some sort of tax adjustment rules. ${ }^{8}$ Many other countries have flat rate deductions; these are easier to control but more unfair, and our political climate does not allow for them. We have to tax according to accumulated profit. Imagine a restaurant in the countryside and compare it to one in the Stockholm centre. How would you apply a flat rate tax and make it fair? I have seen many attempts but it just doesn't work here.

\section{INFORMALIZING THE FORMAL}

Ruben talks about svart arbete as an ongoing process, interacting with the state's increasing involvement in its inhabitants' daily activities:

The state, those in power, well, we have a larger control of citizens than we had fifty years ago. Way back then it was not that kind of [societal] construction. Svart did not exist. Now everything we do ought to be known. I think 
it [svart arbete] by definition has increased, because there is more control today [and thus ways of measuring lost tax revenues]. But go back fifty or a hundred years and apply the same template as we have today. I do not think it has increased; we just did not think in those terms then.

And he continues with an example which is still in existence today, but only in sectors with unaccountable waste, such as restaurants and fresh food providers:

Well, hell, if you had a grocery in the 1950s, if you needed five kg of butter to bake on a Saturday you just took it home. Today, it ought to be taxed; otherwise it is wrong. It wasn't like that before. That's why it [svart arbete] has increased by definition.

Ruben reflects on how the state is seen as having more insight into households' economies, and at the same time more explicitly separates the private from the public. Larissa Adler Lomnitz (1988) aptly described the interrelation between the formalization of systems and people's responses which take the form of increasingly informal activities. She argued that, with the growing bureaucratic formalization of exchanges in society, there will be a similar growth in informal mechanisms which might mirror the increase in Swedish svart arbete. Although strengthening the relations within such groups, these informal activities fracture society (ibid.: 53 ). In the Swedish context, we can see loose-knit networks of craftsmen, for example those that Larry, the coastguard, and Tomas, the craftsman, referred to. They help each other in reciprocal networks, omitting the state and also taxes, fees and so on.

Informal purchases of work can be a result of adaptations to laws and regulations which are perceived to be contradictory. With perceived increased incongruities in laws and regulations, the cheating can expand. Lars sees svart arbete as a result of this. He works within the construction sector and is (as seen earlier) positive with regard to the svart practices as a criticism of the state:

The [political] majority is incredible. I mean, the sector where I work is sensitive to political decisions. So now they are back, these ROT deductions. ${ }^{9}$ For a period VAT was differentiated between materials and work. No fool would then buy materials, just a bloody lot of working hours. Then you had to fool around with that type of nonsense. 
What Lars was referring to was the change of wording on invoices, minimizing the costs for materials and changing as much as possible to become work-which is then subsidized. The increasing formalization of society (Adler Lomnitz 1988), for example through the 'explosion of rules' (Ahrne and Brunsson 2004), was able to provide a background for how the possibilities for transacting spart arbete also increase. It does not erase svart arbete, just makes it look different.

Informal transactions of work flourish not only between people who are socially related or within interest-based groups. Instead they can almost become the norm, feasible between complete strangers. Swedes wanting to acquire a service svart rarely have a problem finding one. Limningers who want to buy services svart only need to ask cautiously, in ambiguous language: I don't need an invoice, but can I get a jolly good price or can you do it at the weekend?

Börje sums up what many seem to believe. People have always exchanged. It's a natural part of life:

You fix this and I'll fix that. But I do not think that's working svart, although it is in the grey zone. If you are tough [on interpreting the law]. I think it's congenial with this market trade. Because that's what it is. It's exchanging all the time, either exchanging services or exchanging money; whether there are goods or services. They have always existed and will always exist. You can never do away with this legally.

\section{Formalizing the Informal: SHARE ECONOMY}

There are exceptions. Mona, a midwife, says that it does not feel as if we want to share and care like we used to. Society is harder, more inhuman, she says. People care less and less for other people, except for those at the very core and the immediate family. She is convinced that this climate of uncaring has a larger impact than we would like to admit. It creeps in, she says: in the beginning people might object, then you get accustomed and used to it, and thus accommodate this egoistic feeling.

If we buy into Mona's reasoning, it is valid to question if the centennial tax law as well as the rise of the sharing economy was a sign of the times; that it reflected a society where fewer and fewer people 'care' about each other. The law that was seen as successful at the time (cf. Lodin 2011) both politically and in its legal construction turned a blind eye to people's need for everyday exchanging. All of a sudden a lot of exchanges that pre- 
viously had been barter became svart arbete. Barter rings were for a time seen as an alternative-with no money involved-but these were quelled when the Agency recognized in a writ that all exchanges taking place within a barter ring or any other type of organized exchanges ought to be subject to taxation (Skatteverket 2009b; cf. Björklund Larsen 2013a).

Organized bartering has existed for a long time, with Ithaca HOURS (Maurer 2005) and LETS (Williams 2012) being just two examples. What can be considered barter has recently expanded into the flourishing arena of exchanges in the so-called sharing economy.

This proliferation has been greatly helped by society's increased digitization and the abundance of web- and app-based applications. Sharing economy practices have increased for a number of reasons: it is practical to share, as you do not have to own or maintain things; it is more economical for the same reason; it is sustainable as not so many things have to be produced and can be used more widely; and it can solve allocation problems, such as getting a ride in sparsely populated neighbourhoods (Alexius et al. 2017). Not all of the so-called sharing economy practices can be defined as creating reciprocal relations: Airbnb and Uber might disguise themselves in 'sharing terms', but their endeavours are driven by plain commercial interests. Theirs are just two of many instances in the sharing economy where corporations take on the role of a broker: Airbnb and Uber are intermediaries providing digital platforms where a person in need can find (underused) services and things offered by other private persons.

From these various examples-yes, most exchanges can create some type of relation. At one end of the continuum of exchanges that create relations there is altruistic helping and sharing; at the other extreme there are pure market exchanges. When does an exchange become sharing instead of expecting something in return (Widlok 2013)? Thomas Widlok proposed that it is the motive to give that is lacking. The act of sharing is done for its own sake (ibid.: 16); it is a complex form of interactions that starts with a demand rather than an offering (ibid.: 22).

Regardless of intentions and reasons for sharing and bartering, the Agency has a definite stance on what is taxable or not (Skatteverket 2009b, 2016). Depending on the status of the provider of the service/thingself-employed or private person-income from the sharing economy is taxable to the same extent as any other income, and the type of recompense does not matter (Skatteverket 2016: 17). 
The inherent properties of how services are exchanged are one challenge for the Agency. Participation in the sharing economy increases tax errors (Skatteverket 2016: 4). It is both more difficult to declare income from 'sharing something' as the rules are complicated, and when income is difficult to account for there are obviously problems in controlling and auditing such activities. The Agency is cautious regarding the sharing economy. It does not advocate for changing legislation, but raises concerns about the erosion of traditional roles: customer-provider; investorproject owner; employer-employee; lender-borrower. Who reports what to the Agency is not as clear cut in the sharing economy. The implication is that the sharing economy challenges the Agency's strategy; that on the one hand it should be easy to report, and pay, the right tax, and on the other hand it should be difficult to err. The Agency does not have the right tools and administrative routines to handle the sharing economy. Tax matters here direct the limelight away from the law itself and onto the application and practice of the law at the Agency as regards these new exchange practices.

The problems with correct tax in the sharing economy that the Agency points to are not new. It is in the new forms of bartering; the explosive increase of such exchanges being helped by the new digital platforms. ${ }^{10}$

From an Agency perspective, it is when the calculative and organizational element in bartering kicks in that such exchanges become taxable. The Agency cannot overlook such exchanges any more in the way it could when they were less organized, scattered and performed through informal networks (yet not barter rings; see above). Such services are performed for a variety of reasons, yet their public organization makes all of them subject to tax. It is a fair nation we live in, is it not-where all are treated equitably?

The sharing economy illustrates that the way in which exchanges are performed between private persons will not necessarily make relations better. However, the feedback offered for a certain service makes who the provider is more explicit. The ratings demanded by participants that are so essential for digital platforms provide a constant negotiation of relations between exchangers. Someone with good ratings is a person you inherently trust and will use for a service. The proliferation of good exchanges makes for successful participation in the sharing economy.

Yet shared things can also be socially attractive as they sustain social cohesion in neighbourhoods. We share with and thereby care for our community, while also brokering a good deal (Björklund Larsen 2013b). 


\section{CONCLUSION}

Following Mary Douglas's initial concerns about human solidarity being created by exchanging, it is valid to ask whether such solidarity is possible in Sweden with the current tax law in place. If Börje is right about that people have always exchanged, to change people's behaviour is not that easy for the state, especially if they have to pay more dearly for it. But as we have seen, the Agency has actually succeeded in implementing a simplified tax system while also concealing issues that are difficult to legitimize. Most importantly they aim to treat people equitably. This increases reciprocity.

Like most other people in the world Swedes continuously exchange. Yet direct exchanges between people keep the state outside the deal. Such exchanges are justifiable among the Limningers as long as they are not too organized or happen too often, do not have too much value, are not performed by professionals in their working time or by a complete stranger. When Limningers talk about cash payments for informal purchases, it is the small and almost negligible amounts that are acceptable; aspects of unacceptability appear in the size of the deal, the type of recompense and the organizational form. The Limningers know about the law, but don't pay too much attention to it if certain conditions are in place. The acceptable purchase of svart arbete is private and hidden, but set against a public reference to what constitutes economic activities.

For example, bartering, in the sense of keeping money out of the deal, makes the direct exchanges more acceptable. Yet even if money is sometimes used, there are many ways to justify this, for example by invoking a closer relationship. Settling the exchange with money makes the links to market and state more pertinent, and the svart deal becomes more explicitly an act of cheating. Therefore, even cash-settled deals are often referred to as barters in order to create a reverse disentanglement, away from the formal market and closer to the realm of social exchange.

The Agency seems to go along with this-unless provoked, as it was with Sven's, the employee expert, test of limits before an exchange was recognized as taxable. What he tested was how close the relationship between exchangers can be and how small a value the exchange can amount to. In this case the Agency read the law to the letter, but it mostly let such exchanges pass. As seen above, it knows that there is a myriad of exchanges that ought to be subject to tax assessment according to a strict interpretation of the law. For various reasons these exchanges should not be subject to tax: they are not publicly spoken about, as it would be seen as an intrusion into people's everyday lives; these exchanges create and 
maintain reciprocal relations among citizens; and if assessed for tax they would threaten the Agency's legitimacy. I propose that the Agency actually increases its legitimacy by interpreting the law 'generously' and instead focusing on making sure that all taxpayers are treated equally and made to do what all others are doing. Tax compliance is then achieved as a copy-cat and equality reciprocal relation. This is also why horse management can be viewed somewhat suspiciously. It is deemed an activity for the privileged and thus sits badly with the idea of Swedish equality.

\section{Notes}

1. It is noteworthy that the Agency only collects taxes; it has nothing to do with their (re)distribution.

2. These estimates were obtained through extrapolation of interview survey methods, and I take that reciprocity here implies being paid in kind.

3. Presentation by Andreas Voxberg, Business Intelligence Expert at the Agency. 5.8.2016.

4. See also Björklund Larsen (2010: 141) for a comparative interpretation of this event.

5. What initially seemed like quite simple questions became quite encompassing when the analysts developed their thinking. Finally, they stated five questions:

1. Are the regulations and the legal framework unclear? Here we can draw upon compliance work looking at the law itself and how the Agency has interpreted the law and developed it into regulations and information to be followed.

2. Studying how common the obvious faulty deductions are is an attempt to quantify the existence of such faults among the Swedish population at large. These quantifications could for example become part of the tax gap calculations.

3. The question of how other taxable entities are affected directs attention towards the legitimacy of the Agency. If taxpayers believe that other citizens pay their dues, they will continue to comply with what they owe.

4. What are the consequences resulting from the rapid expansion of the selfemployed? This question builds on the replies to the previous questions and thus prepares for the more encompassing and final question.

5. How to identify the risks (to the Agency) from these deductions? (Björklund Larsen 2017: 81-82).

6. The Agency has devoted a lengthy, in-depth writ to the difference between a hobby and commercial activity (Skatteverket 2009a, Writ 131 342327-09/111). 
7. The government has been encouraging entrepreneurship by facilitating the registration of small corporations or as self-employment. It is a very easy task to complete, but a follow-up is lacking. Such registrations have also been abused for various types of dubious economic activities.

8. In Swedish, jämkningsregler.

9. ROT (reparationer, ombyggnad, tillbyggnad-repairs, refurbishing, attachments) subsidies have been used now and then to boost the building industry, in times of a slack economy. These subsidies could be used for certain types of reconstruction work at private homes with tax deductions up to a given amount.

10. PricewaterhouseCoopers has estimated the value of the sharing economy globally at 123 billion krona; by 2025 the amount will be 2740 billion. Although these are guesstimates, most actors seem convinced that the sharing economy is here to stay and will take up an increasingly large proportion of services exchanged. The production industry will most probably be challenged by increased usage of existing products, but that discussion is for another forum.

\section{LITERATURE}

Adler Lomnitz, Larissa. 1988. Informal Exchange Networks in Formal Systems: A Theoretical Model. American Anthropologist 90 (1): 42-55.

Ahrne, Göran, and Niels Brunsson. 2004. Regelexplosionen. In Regelexplosionen, ed. Göran Ahrne and Nils Brunsson, 199-220. Stockholm: EFI, Stockholm School of Economics.

Alexius, Susanna, et al. 2017. Fler behöver bry sig om delningsekonomin! Accessed May 10, 2017. http://digitalutmaning.se/wp-content/uploads/2016/12/ Ett-dokument-om-delningsekonomin-slutversion.pdf

Björklund Larsen, Lotta. 2010. Illegal yet Licit: Justifying Informal Purchases of Work in Contemporary Sweden. ACTA UNIVE. Stockholm: Stockholm Studies in Social Anthropology N.S. 2. http://su.diva-portal.org/smash/record. jsf?pid=diva2:287414

- 2013a. Buy or Barter? Illegal yet Licit Purchases of Work in Contemporary Sweden. Focaal Journal of Global and Historical Anthropology 66: 75-87. http://www.ingentaconnect.com/content/berghahn/focal/2013/ 00002013/00000066/art00008

. 2013b. Moulding Knowledge into a Legal Complex: Para-Ethnography at the Swedish Tax Agency. Journal of Business Anthropology 2: 209-231. http://ej.lib.cbs.dk/index.php/jba/article/view/4159

. 2015. 'Common Sense' at the Swedish Tax Agency. Transactional Boundaries Separating Taxable and Tax-Free Income. Critical Perspectives on Accounting 31: 75-89. 
2017. Shaping Taxpayers. Values in Action at the Swedish Tax Agency. Oxford: Berghahn Books.

Cowell, Frank. 1990. Cheating the Government: The Economics of Evasion. Cambridge, MA: MIT Press.

Davis, John. 1992. Exchange. Minneapolis: University of Minnesota Press.

Falkinger, Josef. 1995. Tax Evasion, Consumption of Public Goods, and Fairness. Journal of Economic Psychology 16 (1): 63-72.

Folger, Robert G. 1986. Rethinking Equity Theory. In Justice in Social Relations. Critical Issues in Social Justice, ed. Hans Werner Bierhoff, Ronald L. Cohen, and Jerald Greenberg, 145-162. Springer US. http://link.springer.com/ chapter/10.1007/978-1-4684-5059-0_8

Frey, Bruno S., and Benno Torgler. 2007. Tax Morale and Conditional Cooperation. Journal of Comparative Economics 35: 136-159. http://www. sciencedirect.com/science/article/pii/S0147596706000849

Graeber, David. 2001. Toward an Anthropological Theory of Value: The False Coin of Our Own Dreams. New York: Palgrave Macmillan.

Gregory, C.A. 1994. Exchange and Reciprocity. Companion Encyclopaedia of Anthropology: 911-939.

Gribnau, Hans. 2015. Taxation, Reciprocity and Communicative Regulation. Tilburg Law Review 20: 191-212. http://booksandjournals.brillonline.com/ content/journals/10.1163/22112596-02002009

Hart, Keith. 2001. Informal Economy. In International Encyclopaedia of Social and Behavioural Sciences, 845-846. Oxford: Elsevier.

Humphrey, Caroline, and Stephen Hugh-Jones. 1992. Introduction: Barter, Exchange and Value. In Barter, Exchange, and Value: An Anthropological Approach, ed. C. Humphrey and S. Hugh-Jones, 1-20. Cambridge: Cambridge University Press.

Latour, Bruno. 2015. The Powers of Association. The Sociological Review 32 (1_suppl):264-280.

_. 2006. Purchasing and Performing Undeclared Work in Sweden. Part 1: Results from Various Studies. Solna: Skatteverket.

Ledeneva, A.V. 1998. Russia's Economy of Favours: Blat, Networking, and Informal Exchange. Cambridge University Press.

Lodin, Sven-Olof. 2011. The Making of Tax Law: The Development of the Swedish Tax System. Amsterdam: Iustus Förlag AB. http://www.ibfd.org/IBFDProducts/Making-Tax-Law-Development-Swedish-Tax-System

Maurer, Bill. 2005. Mutual Life, Limited: Islamic Banking, Alternative Currencies, Lateral Reason. Princeton, NJ: Princeton University Press.

Mauss, Marcel. 2002 [1990]. The Gift. London: Routledge.

Pardo, Italo. 1996. Managing Existence in Naples: Morality, Action, and Structure. Cambridge: Cambridge University Press.

Sahlins, Marshall D. 1972. Stone Age Economics. London: Routledge. 
Schor, Juliet. 2016. Debating the Sharing Economy. Journal of Self-Governance and Management Economics 4 (3): 7-22. https://www.ceeol.com/contentfiles/document-431329.pdf

Skatteverket. 2005. Right from the Start. Solna: Skatteverket.

- 2007. Svartköp och svartjobb i Sverige. Del 2: Möjliga åtgärder mot svartarbete och bidragsfusk. Solna: Skatteverket.

- 2008. Mätning av skatteverkets effekter på dess omgivning. Solna: Skatteverket.

—. 2009a. Hästverksamhet - gränsdragningen mellan hobby- och näringsverksamhet. Writ 131 342327-09/111. Solna: Skatteverket.

- 2009b. Beskattning av medlem i bytesring. Writ 131 319224-09/111. Solna: Skatteverket.

- 2016. Delningsekonomi. kartläggning och analys av delningsekonomins påverkan på skattesystemet (Rapport 131129 651-16/113).

Stridh, Anders, and Lennart Wittberg. 2015. Från Fruktad Skattefogde till Omtyckt Servicemyndighet. Solna: Skatteverket.

Taylor, Natalie. 2002. Understanding Tax Payer Attitudes through Understanding Taxpayer Identities. In Taxing Democracy: Understanding Tax Avoidance and Evasion, ed. Valerie A. Braithwaite, 71-92. Aldershot: Ashgate Publishing, Ltd. Westerman, Pauline. 2014. Reciprocity: A Fragile Equilibrium. Netherlands Journal of Legal Philosophy 2 (43): 172-184.

Widlok, Thomas. 2013. Allowing Others to Take What Is Valued. HAU: Journal of Ethnographic Theory 3 (2): 11-31.

Williams, Colin C. 2012. The New Barter Economy: An Appraisal of Local Exchange and Trading Systems (LETS). Journal of Public Policy 16 (1): 85-101.

Zelizer, Viviana. 2005. The Purchase of Intimacy. Princeton, NJ: Princeton University Press.

Open Access This chapter is licensed under the terms of the Creative Commons Attribution 4.0 International License (http://creativecommons.org/licenses/ by $/ 4.0 /)$, which permits use, sharing, adaptation, distribution and reproduction in any medium or format, as long as you give appropriate credit to the original author(s) and the source, provide a link to the Creative Commons license and indicate if changes were made.

The images or other third party material in this chapter are included in the chapter's Creative Commons license, unless indicated otherwise in a credit line to the material. If material is not included in the chapter's Creative Commons license and your intended use is not permitted by statutory regulation or exceeds the permitted use, you will need to obtain permission directly from the copyright holder.

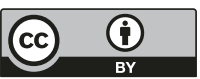

